\title{
EFFECT OF HEALTH BEHAVIORS ON METABOLIC CONTROL IN PATIENTS WITH TYPE 2 DIABETES
}

\section{WPŁYW ZACHOWAŃ ZDROWOTNYCH NA KONTOLĘ METABOLICZNĄ U PACJENTÓW Z CUKRZYCĄ TYPU 2}

\author{
Aneta Grochowska ${ }^{1(D, E, F)}$, Barbara Kubik ${ }^{1(A, E, F)}$, tucja Turska $^{2(B, C, D)}$ \\ ${ }^{1}$ Department of Nursing, University of Applied Sciences in Tarnow, Poland \\ ${ }^{2}$ Non-Public Health Care Center in Krynica Zdrój, Branch in Klęczany, Poland
}

Authors' contribution Wkład autorów: A. Study design/planning zaplanowanie badań B. Data collection/entry zebranie danych C. Data analysis/statistics dane - analiza i statystyki D. Data interpretation interpretacja danych E. Preparation of manuscript przygotowanie artykułu F. Literature analysis/search wyszukiwanie i analiza literatury G. Funds collection zebranie funduszy

\section{Summary}

Background. Diabetes is a chronic and progressive disease affecting all areas of life. It requires not only pharmacological treatment, but more importantly lifestyle changes, weight reduction, and dietary modifications. Improperly treated, it causes numerous complications that can lead to disability and even death.

Material and methods. This study aimed to evaluate the effect health behaviors have on metabolic compensation in patients with type 2 diabetes. The study consisted of 116 patients. The inclusion criteria included type 2 diabetics between the ages of 40 and 65 who were diagnosed by a diabetologist for a minimum of one year. The KomPAN questionnaire, PSS 10 scales, International Physical Activity Questionnaire (IPAQ), and analysis of medical records were used to evaluate these effects. Of the 116 patients, 104 ( 54 women and 50 men) met the inclusion criteria and were used in data analysis.

Results. No patient in our study met all the criteria for metabolic compensation of type 2 diabetes. Postprandial glucose concentrations were the best-compensated parameter. Whereas, LDL concentrations were the least compensated parameter. In individuals with fewer unhealthy dietary practices compensated more significantly for their diabetes. Seventy-eight percent of women and $90 \%$ of men with BMIs consistent with stages I and II overweight or obesity had abnormal fasting glucose levels.

Conclusions. The factors that significantly impact diabetes compensation are diet, stress levels, and physical activity levels. The assessment of a patient's nutritional knowledge correlates with their dietary assessment.

Keywords: metabolic compensation, type 2 diabetes, health behaviors

\section{Streszczenie}

Wprowadzenie. Cukrzyca należy do chorób przewlekłych i postępujących i wpływa na wszystkie dziedziny życia. Wymaga nie tylko leczenia farmakologicznego, ale przede wszystkim zmiany stylu życia, redukcji masy ciała i modyfikacji diety. Niewłaściwie leczona powoduje wiele powikłań, które prowadzą do niepełnosprawności, a nawet śmierci.

Materiał i metody. Celem pracy była ocena wpływu zachowań zdrowotnych chorych z cukrzycą typu 2 na wyrównanie metaboliczne cukrzycy. Badaną grupę stanowiło 116 pacjentów. Kryterium włączenia pacjentów do grupy badanej był wiek między 40 a 65 rokiem życia oraz stwierdzona przez lekarza diabetologa cukrzyca typu 2 trwajaca minimum rok. Jako narzędzie badawcze wykorzystano: kwestionariusz KomPAN, skale PSS 10, Międzynarodowy Kwestionariusz Aktywności Fizycznej IPAQ oraz analizę dokumentacji medycznej. Z grupy 116 pacjentów, 104 osoby (54 kobiety i 50 mężczyzn) spełniły kryteria i zostały włączone do analizy.

Wyniki. Badania wykazały, że nie było żadnego pacjenta spełniającego wszystkie kryteria wyrównania metabolicznego cukrzycy typu 2. Najlepiej wyrównanym parametrem był poziom glikemii poposiłkowej. Najrzadziej wyrównanym parametrem było stężenie frakcji LDL. Osoby z małym natężeniem cech diety niezdrowej miały znacznie częściej wyrównana cukrzycę. 78\% kobiet i 90\% mężczyzn, których BMI świadczyło o nadwadze lub otyłości I i II stopnia charakteryzowało się nieprawidłowym poziomem glukozy na czczo.

Wnioski. Czynnikami mającymi istotny wpływ na kompensację cukrzycy są sposób odżywiania, poziom stresu i poziom aktywności fizycznej. Ocena wiedzy żywieniowej koreluje $\mathrm{z}$ oceną sposobu ży wienia.

Słowa kluczowe: wyrównanie metaboliczne, cukrzyca typu 2, zachowania zdrowotne
Tables: 6
Figures: 0

References: 34

Submitted: 2021 Jul 22

Accepted: 2021 Oct 8

Grochowska A, Kubik B, Turska Ł. Effect of health behaviors on metabolic control in patients with type 2 diabetes. Health Prob Civil. 2021; 15(4): 282-290. https://doi.org/10.5114/hpc.2021.109905

Address for correspondence / Adres korespondencyjny: Aneta Grochowska, Department of Nursing, University of Applied Sciences in Tarnow, Mickiewicza 8, 33100 Tarnów, Poland, e-mail: apea1@op.pl, phone: +48146316614

ORCID: Aneta Grochowska https://orcid.org/0000-0002-1371-7655, Barbara Kubik https://orcid.org/0000-0002-4259-392X

Copyright: (C) Pope John Paul II State School of Higher Education in Biała Podlaska, Aneta Grochowska, Barbara Kubik, Łucja Turska. This is an Open Access journal, all articles are distributed under the terms of the Creative Commons Attribution-NonCommercial-ShareAlike 4.0 International (CC BY-NC-SA 4.0) License (http:// creativecommons.org/licenses/by-nc-sa/4.0/), allowing third parties to copy and redistribute the material in any medium or format and to remix, transform, and build upon the material, provided the original work is properly cited and states its license. 


\section{Introduction}

At the end of the 20th century, the World Health Organization established the definition of diabetes which is still in use today. According to the definition, diabetes is a group of metabolic diseases characterized by hyperglycemia due to abnormalities in the release or action of insulin or both. Long-standing hyperglycemia leads to a functional disorder ultimately leading to diseases of the heart, blood vessels, peripheral nerves, eyes, and kidneys [1,2].

The number of patients diagnosed with type II diabetes continues to increase. It's estimated that 415 million people worldwide or $8.8 \%$ of adults aged $20-79$ have diabetes [3]. Ninety to $95 \%$ of these patients are diagnosed with type 2 diabetes. Researchers predicted that the number of diabetic patients may increase to 592 million by 2035 [4].

"Diabetes, the hidden pandemic, 2014 edition" - a report prepared by the Polish Diabetes Association estimates that three million people suffer from diabetes in Poland, while approximately one million people are not aware they have the disease or are struggling with a prediabetes state constituting $12-15 \%$ of society [5,6]. Diabetes is the sixth most frequent cause of death. One in four people above the age of 65 and every second person over 80 are ill from diabetes. The number of patients with type 2 diabetes continues to grow due to the obesity pandemic, lack of regular physical activity, improvements in diagnosing the disease, longer life expectancy, and increasingly effective treatment of its complications [7,8].

Diabetes influences every aspect of life. The treatment of diabetes requires not only pharmacological medications but changes in lifestyle, weight loss, and dieting are also required. Alcohol consumption, cigarette smoking, and stress are also critical factors that influence the effectiveness of diabetic treatments. Despite various forms of education, patients frequently do not understand the gravity of the situation and often forget about the first principles of treatment: self-control and self-care $[9,10]$.

As the number of diabetic patients increases so do the complications. These complications have the greatest impact on patients and influence the length and quality of life. Over time, diabetes can cause damage to the heart, blood vessels, eyes, kidneys, and nerves. Research has shown that adults with diabetes have a two-to three-fold increased risk of heart attacks and strokes [11]. In addition, diabetes is responsible for $2.6 \%$ of blindness cases worldwide [12].

Changing the health behaviors of patients is an important element of therapy and may prevent chronic complications. Behavioral therapy plays a crucial role in teaching self-care: the actions that control the disease on a daily basis [13]. Patients should be able to manage their disease and achieve proper carbohydrate and lipid metabolism as well as healthy arterial blood pressure. To achieving these diabetic parameters, treatment requires the focus to be on intensifying preventive healthcare, education, and therapy. The educational component should focus on preparing patients to make health-promoting actions and cooperate with the process of treatment, maintenance, rehabilitation, and self-care. However, a significant number of patients feel the pharmacological treatment is the most important. They do not realize the positive influences increased physical activity and a change in eating habits can have on therapy $[2,9]$.

The study aimed to assess how a patient's health behaviors can influence the metabolic control of type 2 diabetes.

\section{Material and methods}

The health behaviors of the study participants were obtained through the use of questionnaires. The medical record was also used to obtain the needed objective data. To check the participants' attitudes and eating habits we used the KomPAN questionnaire for people aged 16 to 65 prepared by the Polish Academy of Sciences, Human Nutrition Committee, Eating Behaviour Group [14].

Stress levels were accessed using the Polish adaptation of the PPS scale developed by Juczyński and OgińskaBulik [15]. The short version of the International Physical Activity Questionnaire was used to measure the level of physical activity [16].

Nourishment appraisal was made based on the anthropometric measurements of body weight, height, waist size, and hip size. Body Mass Index and Waist-hip ratio was determined according to the WHO recommendations regarding these measurements. The medical records were used to evaluate the level of metabolic control in the participants. The analysis of carbohydrate and lipid metabolism, as well as arterial blood pressure, was performed. The level of metabolic control was assessed based on 9 parameters (glucose levels during fasting and after eating, glycated hemoglobin, cholesterol, HDL, LDL, triglycerides, and systolic and diastolic blood pressure) following the Polish Diabetes Association recommendations [13]. 
This research project was carried out in the Non-Public Health Care Center in Krynica Zdrój, Diabetes Centre branch located in Klęczany, Poland. The director of the facility consented to the research. The research was performed from October 2017 to February 2018. The inclusion criterion for patients includes age between 40 and 65, and type 2 diabetes lasting at least one year, as diagnosed by a diabetologist.

All participants were active both physically and mentally and had the ability to make decisions on their own. Before the beginning of the study, every respondent was informed about the anonymity of the information obtained. There were 116 patients examined. Patients completed the KomPAN questionnaire and PSS scale on their own. The physical activity examination was made through personal contact with the respondent. There were a total of 104 surveys completed for analysis. Twelve questionnaires about nutrition were rejected due to them being answered incompletely. The study consisted of 54 women and 50 men.

The chi-squared test was used to verify relations between variables. The statistics were calculated with Dell Statistica ver. 13 and Microsoft Office (Excel) 365 ProPlus. Data are presented as a mean with standard deviation, min and max, or using the count, percentage, and median. A p-value of $<0.05$ was chosen as the critical level of significance.

\section{Results}

The examined group was divided into two categories: men and women. Women constituted 52\% and men $48 \%$ of the studied population (Table 1 ).

Table 1. Demographic characteristics of the respondents

\begin{tabular}{|c|c|c|c|}
\hline \multicolumn{2}{|c|}{ Variable } & \multirow{2}{*}{$\begin{array}{c}\mathbf{N} \\
54 \\
\end{array}$} & \multirow{2}{*}{$\begin{array}{c}\% \\
52 \% \\
\end{array}$} \\
\hline$C_{0}$ & Women & & \\
\hline Sex & Men & 50 & $48 \%$ \\
\hline \multirow{3}{*}{ Age } & 40-50 years old & 36 & $35 \%$ \\
\hline & $51-60$ years old & 37 & $36 \%$ \\
\hline & 61-65 years old & 31 & $29 \%$ \\
\hline \multirow{4}{*}{ Educational background } & Elementary & 4 & $3.8 \%$ \\
\hline & Professional training & 41 & $39.4 \%$ \\
\hline & Secondary & 39 & $37.5 \%$ \\
\hline & Higher & 20 & $19.3 \%$ \\
\hline \multirow{2}{*}{ Place of living } & Village & 82 & $78.8 \%$ \\
\hline & City & 22 & $21.2 \%$ \\
\hline \multirow{4}{*}{ Professional activity } & Active & 47 & $45.1 \%$ \\
\hline & Retirement or pension & 38 & $36.5 \%$ \\
\hline & Unemployed & 7 & $6.7 \%$ \\
\hline & Casual job & 12 & $11.7 \%$ \\
\hline
\end{tabular}

The influence of presented behaviors on type 2 diabetes

The results presented in Table 2 show the slight difference in fasting glucose measurements between men and women $(\mathrm{p}<0.0446)$. There is also a statistically significant difference in postprandial blood glucose levels between men and women $(\mathrm{p}<0.018)$. There are no significant differences in regards to diastolic pressures, but a statistically significant difference in systolic pressures was noted $(\mathrm{p}<0.045)$. When it comes to lipid metabolism, gender differences were seen in the HDL fraction $(\mathrm{p}<0.022)$ (Table 2). 
Table 2. The level of metabolic management of the examined population

\begin{tabular}{|c|c|c|c|c|c|c|}
\hline & & \multicolumn{2}{|c|}{ Women } & \multicolumn{2}{|c|}{ Men } & \multirow{2}{*}{$\mathbf{p}$} \\
\hline & & $\mathbf{n}$ & $\%$ & $\mathbf{n}$ & $\%$ & \\
\hline \multirow{2}{*}{$\begin{array}{c}\text { Fasting plasma } \\
\text { glucose level }\end{array}$} & Normal & 12 & $22 \%$ & 4 & $8 \%$ & \multirow{2}{*}{0.0446} \\
\hline & Above normal & 42 & $78 \%$ & 46 & $92 \%$ & \\
\hline \multirow{2}{*}{$\begin{array}{c}\text { Postprandial } \\
\text { glycemia }\end{array}$} & Normal & 42 & $78 \%$ & 28 & $56 \%$ & \multirow{2}{*}{0.0180} \\
\hline & Above normal & 12 & $22 \%$ & 22 & $44 \%$ & \\
\hline \multirow{2}{*}{ HBA1C } & Normal & 37 & $69 \%$ & 27 & $54 \%$ & \multirow{2}{*}{0.1284} \\
\hline & Above normal & 17 & $31 \%$ & 23 & $46 \%$ & \\
\hline \multirow{2}{*}{ Systolic pressure } & Normal & 23 & $43 \%$ & 12 & $24 \%$ & \multirow{2}{*}{0.0450} \\
\hline & Above normal & 31 & $57 \%$ & 38 & $76 \%$ & \\
\hline \multirow{2}{*}{ Diastolic pressure } & Normal & 35 & $65 \%$ & 29 & $58 \%$ & \multirow{2}{*}{0.4754} \\
\hline & Above normal & 19 & $35 \%$ & 21 & $42 \%$ & \\
\hline \multirow{2}{*}{ Cholesterol } & Normal & 24 & $44 \%$ & 28 & $56 \%$ & \multirow{2}{*}{0.2390} \\
\hline & Above normal & 30 & $56 \%$ & 22 & $44 \%$ & \\
\hline \multirow{2}{*}{ HDL } & Normal & 32 & $59 \%$ & 40 & $80 \%$ & \multirow{2}{*}{0.0220} \\
\hline & Above normal & 22 & $41 \%$ & 10 & $20 \%$ & \\
\hline \multirow{2}{*}{ LDL } & Normal & 5 & $9 \%$ & 6 & $12 \%$ & \multirow{2}{*}{0.6498} \\
\hline & Above normal & 49 & $91 \%$ & 44 & $88 \%$ & \\
\hline \multirow{2}{*}{ TG } & Normal & 16 & $30 \%$ & 13 & $26 \%$ & \multirow{2}{*}{0.6800} \\
\hline & Above normal & 38 & $70 \%$ & 37 & $74 \%$ & \\
\hline
\end{tabular}

The mean values used to assess the metabolic control of diabetes is presented in Table 3. The mean value for HbA1c was $6.74 \%$ for women and $7.18 \%$ for men. An average value of $\leq 7 \%$ was only achieved in women (69\%). The average fasting glucose level was $132.13 \pm 29.25$ ranging from 85 to $217 \mathrm{mg} / \mathrm{dl}$ for women, and $150.54 \pm 39.01$ for men with a range from 97.3 to $274 \mathrm{mg} / \mathrm{dl}$ (Table 3).

Table 3. Detailed parameter values estimating metabolic management of diabetes of the examined group

\begin{tabular}{|c|c|c|c|c|c|c|c|c|}
\hline \multicolumn{2}{|c}{} & Average & SD & Min & Max & Q1 & Q2 & Q3 \\
\hline \multirow{2}{*}{ Fasting plasma glucose level } & Women & 132.13 & 29.25 & 85.00 & 217.00 & 111.95 & 130.10 & 147.88 \\
\cline { 2 - 8 } & Men & 150.54 & 39.01 & 97.30 & 274.00 & 120.50 & 141.00 & 171.00 \\
\hline \multirow{2}{*}{ Postprandial glycemia } & Women & 129.45 & 27.68 & 98.00 & 216.00 & 113.25 & 122.65 & 131.00 \\
\cline { 2 - 9 } & Men & 140.97 & 27.83 & 96.60 & 208.00 & 121.33 & 130.65 & 165.50 \\
\hline \multirow{2}{*}{ HBA1C } & Women & 6.74 & 1.34 & 4.80 & 10.50 & 5.73 & 6.35 & 7.50 \\
\cline { 2 - 9 } & Men & 7.18 & 1.27 & 5.20 & 9.60 & 6.20 & 6.80 & 8.51 \\
\hline \multirow{2}{*}{ Systolic pressure } & Women & 139.35 & 19.81 & 110.00 & 200.00 & 121.25 & 140.00 & 160.00 \\
\cline { 2 - 9 } & Men & 147.60 & 19.65 & 120.00 & 220.00 & 140.00 & 140.00 & 160.00 \\
\hline \multirow{2}{*}{ Diastolic pressure } & Women & 83.33 & 7.77 & 70.00 & 100.00 & 80.00 & 80.00 & 90.00 \\
\cline { 2 - 9 } & Men & 87.60 & 10.98 & 80.00 & 130.00 & 80.00 & 80.00 & 90.00 \\
\hline \multirow{2}{*}{ Cholesterol } & Women & 5.08 & 1.23 & 2.56 & 7.72 & 4.18 & 5.21 & 5.89 \\
\cline { 2 - 9 }$y$ & Men & 4.98 & 1.20 & 3.00 & 9.07 & 4.05 & 4.81 & 5.87 \\
\hline \multirow{2}{*}{ LDL } & Women & 1.49 & 0.66 & 0.62 & 4.32 & 1.13 & 1.33 & 1.70 \\
\cline { 2 - 9 } & Men & 1.33 & 0.40 & 0.65 & 2.63 & 1.08 & 1.26 & 1.60 \\
\hline \multirow{2}{*}{ TG } & Women & 2.78 & 0.92 & 1.38 & 5.40 & 2.05 & 2.56 & 3.26 \\
\cline { 2 - 9 } & Men & 2.88 & 0.91 & 1.34 & 5.01 & 2.32 & 2.60 & 3.51 \\
\hline & Women & 2.25 & 1.05 & 0.64 & 5.30 & 1.58 & 1.98 & 2.75 \\
\cline { 2 - 8 } & Men & 2.35 & 1.06 & 0.55 & 6.02 & 1.66 & 2.21 & 2.71 \\
\hline
\end{tabular}

Analysis of the study shows poor metabolic control of diabetes in the examined population. In this study, we assumed a result above $50 \%$ signifies management of the disease and is equal to obtaining 5 points or more. Forty-one percent of women and $68 \%$ of men were found to have their diabetes controlled. The rest of the patients ( $\mathrm{W}=59 \%$ and $M=32 \%)$ were considered to have partial metabolic control of their diabetes $(p<0.0053)$.

The best metabolic control was achieved by patients within both studied groups that had low levels of stress, showing no statistically significant differences between women and men $(\mathrm{p}<0.9282)$. On the other hand, 
statistical differences were observed between the sexes in regards to the average level of stress $(p<0.0072)$. A higher percentage of people achieving metabolic control with average levels of stress was found in more men compared to women ( $\mathrm{M}=70 \%$ and $\mathrm{F}=40 \%)$. No significant differences were found between patients with high levels of stress.

The majority of participants in our study had an insufficient level of physical activity. There was a statistically significant relationship $(\mathrm{p}<0.0014)$ between sex and metabolic control in patients with low levels of physical activity. Fifty-two percent of men with low levels of activity had metabolic disease compared to women (13\%). However, no significant differences were found between men and women whose level of physical activity was defined as high or moderate. At the same time, these patients had much higher metabolic control of their disease than people with an insufficient level of physical activity (Table 4).

Table 4. Metabolic management of diabetes and physical activity levels of patients.

\begin{tabular}{|c|c|c|c|c|c|c|}
\hline \multirow{2}{*}{ Physical activity } & \multirow{2}{*}{$\begin{array}{c}\text { Metabolic } \\
\text { management }\end{array}$} & \multicolumn{2}{|c|}{ Women } & \multicolumn{2}{|c|}{ Men } & \multirow{2}{*}{$\mathbf{p}$} \\
\hline & & $\mathbf{n}$ & $\%$ & $\mathbf{n}$ & $\%$ & \\
\hline \multirow{2}{*}{ Insufficient level } & yes $(\geq 5)$ & 4 & $13 \%$ & 14 & $52 \%$ & \multirow{2}{*}{0.0014} \\
\hline & no $(<5)$ & 27 & $87 \%$ & 13 & $48 \%$ & \\
\hline \multirow{2}{*}{ Sufficient level } & yes $(\geq 5)$ & 14 & $82 \%$ & 15 & $88 \%$ & \multirow{2}{*}{0.6282} \\
\hline & no $(<5)$ & 3 & $18 \%$ & 2 & $12 \%$ & \\
\hline \multirow{2}{*}{ High level } & yes $(\geq 5)$ & 4 & $67 \%$ & 5 & $83 \%$ & \multirow{2}{*}{0.5050} \\
\hline & no $(<5)$ & 2 & $33 \%$ & 1 & $17 \%$ & \\
\hline
\end{tabular}

A history of smoking was shown to influence the control of diabetes in women during this study $(9 \%$ of women). Female respondents who never smoked had a statistically significant better compensation for their diabetes $(\mathrm{p}<0.0032)$ than women who currently smoked or had a history of smoking. Among men, there was a statistically significant difference $(\mathrm{p}<0.0041)$ in patients that quitting smoking $(74 \%)$ compared to current and past smokers.

There was a statistically significant difference in metabolic control when a participant's diet was taken into consideration. Patients with a diet low in pro-health features had more frequently uncompensated metabolic disease compared to people with a moderate intensity of pro-health features $(\mathrm{p}<0.0042)$. A statistically significant higher percentage of patients in both groups had low to medium levels of anti-health dietary features $(p<0.041)$. People with low intensities of unhealthy dietary features often achieved a more balanced control of their diabetes compared to people with moderate levels of unhealthy dietary features (Table 5).

Table 5. Metabolic management of diabetes and eating habits of patients

\begin{tabular}{|c|c|c|c|c|c|c|c|}
\hline \multirow{2}{*}{ Diet index } & \multirow{2}{*}{$\begin{array}{c}\text { Intensity of } \\
\text { eating habits }\end{array}$} & \multirow{2}{*}{$\begin{array}{c}\text { Metabolic } \\
\text { management }\end{array}$} & \multicolumn{2}{|c|}{ Women } & \multicolumn{2}{|c|}{ Men } & \multirow{2}{*}{$\mathbf{p}$} \\
\hline & & & $\mathbf{n}$ & $\%$ & n & $\%$ & \\
\hline \multirow{6}{*}{$\begin{array}{l}\text { Health- } \\
\text { promoting } \\
\text { diet index }\end{array}$} & \multirow{2}{*}{ small } & yes $(\geq 5)$ & 11 & $50 \%$ & 27 & $79 \%$ & \multirow{6}{*}{0.0042} \\
\hline & & no $(<5)$ & 28 & $88 \%$ & 15 & $94 \%$ & \\
\hline & \multirow{2}{*}{ moderate } & yes $(\geq 5)$ & 11 & $50 \%$ & 7 & $21 \%$ & \\
\hline & & no $(<5)$ & 4 & $13 \%$ & 1 & $6 \%$ & \\
\hline & \multirow{2}{*}{ high } & yes $(\geq 5)$ & 0 & $0 \%$ & 0 & $0 \%$ & \\
\hline & & no $(<5)$ & 0 & $0 \%$ & 0 & $0 \%$ & \\
\hline \multirow{6}{*}{$\begin{array}{l}\text { Unhealthy diet } \\
\text { index }\end{array}$} & \multirow{2}{*}{ small } & yes $(\geq 5)$ & 21 & $95 \%$ & 33 & $97 \%$ & \multirow{6}{*}{0.0410} \\
\hline & & no $(<5)$ & 28 & $88 \%$ & 15 & $94 \%$ & \\
\hline & \multirow{2}{*}{ moderate } & yes $(\geq 5)$ & 1 & $5 \%$ & 1 & $3 \%$ & \\
\hline & & no $(<5)$ & 4 & $12 \%$ & 1 & $6 \%$ & \\
\hline & \multirow{2}{*}{ high } & yes $(\geq 5)$ & 0 & $0 \%$ & 0 & $0 \%$ & \\
\hline & & no $(<5)$ & 0 & $0 \%$ & 0 & $0 \%$ & \\
\hline
\end{tabular}

A statistically significant relationship was observed between the metabolic control of diabetes in men and current smoking $(\mathrm{p}<0.0138)$, previous smoking $(\mathrm{p}<0.0041)$, and type of alcohol consumed $(\mathrm{p}<0.0014)$. In women, past and present smoking and frequency of alcohol consumption had a statistically significant impact on metabolic control (Table 6). 
Table 6. Metabolic management of diabetes and the use of stimulants.

\begin{tabular}{|c|c|c|c|c|c|c|c|c|c|c|c|}
\hline & & \multicolumn{5}{|c|}{ Women } & \multicolumn{5}{|c|}{ Men } \\
\hline & & \multicolumn{2}{|c|}{ yes $(\geq 5)$} & \multicolumn{2}{|c|}{ no $(<5)$} & \multirow{2}{*}{$\mathbf{p}$} & \multicolumn{2}{|c|}{ yes $(\geq 5)$} & \multicolumn{2}{|c|}{ no $(<5)$} & \multirow[t]{2}{*}{$\mathbf{p}$} \\
\hline & & $\mathbf{n}$ & $\%$ & $\mathbf{n}$ & $\%$ & & $\mathrm{n}$ & $\%$ & $\mathbf{n}$ & $\%$ & \\
\hline \multirow{2}{*}{ Current smoking } & Yes & 4 & $18 \%$ & 5 & $16 \%$ & \multirow{2}{*}{0.8044} & 3 & $9 \%$ & 6 & $18 \%$ & \multirow{2}{*}{0.0138} \\
\hline & No & 18 & $82 \%$ & 27 & $84 \%$ & & 31 & $91 \%$ & 10 & $29 \%$ & \\
\hline \multirow{2}{*}{ Smoking in the past } & Yes & 2 & $9 \%$ & 26 & $81 \%$ & \multirow{2}{*}{0.0000} & 27 & $79 \%$ & 14 & $41 \%$ & \multirow{2}{*}{0.4874} \\
\hline & No & 20 & $91 \%$ & 6 & $19 \%$ & & 7 & $21 \%$ & 2 & $6 \%$ & \\
\hline \multirow{3}{*}{$\begin{array}{l}\text { Smoking in the past } \\
\text { and currently }\end{array}$} & Yes & 1 & $5 \%$ & 7 & $22 \%$ & \multirow{3}{*}{0.0352} & 2 & $6 \%$ & 7 & $21 \%$ & \multirow{3}{*}{0.0041} \\
\hline & No & 15 & $68 \%$ & 11 & $34 \%$ & & 7 & $21 \%$ & 1 & $3 \%$ & \\
\hline & Giving up smoking & 6 & $27 \%$ & 14 & $44 \%$ & & 25 & $74 \%$ & 8 & $24 \%$ & \\
\hline \multirow{6}{*}{$\begin{array}{c}\text { Alcohol } \\
\text { consumption }\end{array}$} & Never & 9 & $41 \%$ & 1 & $3 \%$ & \multirow{6}{*}{0.0044} & 1 & $3 \%$ & 0 & $0 \%$ & \multirow{6}{*}{0.0647} \\
\hline & 1-3 times a month & 9 & $41 \%$ & 17 & $53 \%$ & & 10 & $29 \%$ & 4 & $12 \%$ & \\
\hline & Once a week & 3 & $14 \%$ & 9 & $28 \%$ & & 21 & $62 \%$ & 6 & $18 \%$ & \\
\hline & Few times a week & 1 & $5 \%$ & 5 & $16 \%$ & & 2 & $6 \%$ & 5 & $15 \%$ & \\
\hline & Once a day & 0 & $0 \%$ & 0 & $0 \%$ & & 0 & $0 \%$ & 1 & $3 \%$ & \\
\hline & Few times a day & 0 & $0 \%$ & 0 & $0 \%$ & & 0 & $0 \%$ & 0 & $0 \%$ & \\
\hline \multirow{5}{*}{$\begin{array}{l}\text { Type of alcohol } \\
\text { consumed }\end{array}$} & Beer & 7 & $32 \%$ & 13 & $41 \%$ & \multirow{5}{*}{0.0801} & 24 & $71 \%$ & 5 & $15 \%$ & \multirow{5}{*}{0.0014} \\
\hline & Wine & 7 & $32 \%$ & 7 & $22 \%$ & & 6 & $18 \%$ & 2 & $6 \%$ & \\
\hline & Drinks & 1 & $5 \%$ & 7 & $22 \%$ & & 2 & $6 \%$ & 8 & $24 \%$ & \\
\hline & Strong alcohol & 0 & $0 \%$ & 2 & $6 \%$ & & 0 & $0 \%$ & 2 & $6 \%$ & \\
\hline & None & 7 & $32 \%$ & 3 & $9 \%$ & & 1 & $3 \%$ & 0 & $0 \%$ & \\
\hline
\end{tabular}

\section{Discussion}

Uncontrolled diabetes can lead to numerous metabolic derangements. Diabetes mellitus is associated with a doubling of the risk for cardiovascular (CV) diseases independent of other risk factors. Therefore, no individuals are considered at low CV risk among diabetics. Young patients diagnosed for less than 10 years with diabetes mellitus are considered to be at intermediate CV risk [17]. As a chronic condition, it requires a change in the patient's lifestyle for proper control. The disease's development and metabolic control depend on the maintenance of proper dieting, the intensity of physical activity, the avoidance of stressful situations, and the reduction of stimulants such as cigarettes and alcohol. Annually, the Polish Diabetes Association uploads data informing the patients' about their metabolic control using parameters like glycemic and lipid control, arterial pressure, and body weight [13].

According to the authors' previous studies, no patients were able to achieve all the criteria of metabolic control for diabetes. Research by other authors also confirms these worrying results. No respondent met all the criteria in a survey by Fabian et al. as well. However, a large proportion of the respondents achieved metabolic control of some parameters individually [18]. The proportion of people who attained a systolic blood pressure $<140 \mathrm{mmHg}$ was $43 \%$ for women and $24 \%$ for men, (general 33.5\%), and diastolic blood pressure $<90 \mathrm{mmHg}$ was $65 \%$ for women and $58 \%$ for men (general $72.5 \%$ ). In the study by Fabian et al., the criteria for metabolic management were attained by $16.1 \%$ of the patients for systolic blood pressure and $24.5 \%$ for diastolic blood pressure [18].

Even fewer patients with normal blood pressures were reported in the "The Improvement in Glycaemic Control" research, where only $8.7 \%$ of patients with type 2 diabetes had a blood pressure lower than $130 / 80$ $\mathrm{mmHg}[19]$.

The new guidelines place great emphasis on an important group of CV risk factors in patients with DM. The insulin resistance syndrome includes obesity and other atherosclerotic risk factors (hyperglycemia, hyperinsulinemia, lipid disorders, and arterial hypertension). Such patients have been shown to have elevated levels of proinflammatory and prothrombotic factors, which play a significant role in vascular injury [17].

In our study, the proportion of patients with $\mathrm{HbA} 1 \mathrm{c} \leq 7 \%$ was $69 \%$ for women and $54 \%$ for men (general $61 \%$ ). The average HbA1c was $6.74 \%$ in the group of women and $7.18 \%$ in men. The most balanced parameter of carbohydrate metabolism was postprandial glycemia ( $\mathrm{W}=78 \%$ and $\mathrm{M}=56 \%$ ). These patients had better-balanced carbohydrate metabolism than a group of patients examined during 2006-2009 from the National Register of Diabetic Patients in which, the proportion of patients with a HbA1c $\leq 7 \%$ was only 50\% [20]. In the OPTIMO research study, published in 2011, there were 8842 patients with type 2 diabetes and only $45.3 \%$ of patients had 
a HbA1c $\leq 7 \%$ [21]. Kudaj-Kurowska et al. examined 249 patients with type 2 diabetes with an average BMI of $32.6 \mathrm{~kg} / \mathrm{m}^{2}$. A vast majority of these patients (89\%) were found to have hypertension and an average HbA1c of 7.34\%. A HbA1c $\leq 7.0 \%$ was observed in only half of the patients [22]. It should be noted that the carbohydrate and lipid metabolic control in our examined population rates favorably compared to European and American data. According to the national records available, an average HbA1c among patients with type 2 diabetes is from $6.7 \%$ in Sweden [23] to 7.6\% in France [24]. The percent of patients with LDL cholesterol levels $<100 \mathrm{mg} / \mathrm{dl} \mathrm{have}$ ranged from $5.9 \%$ in Spain [25] to $46.5 \%$ in the US [26].

The best results of our study concerning lipid metabolism were recorded for HDL cholesterol. Fifty-nine percent of women with an average of $1.49 \mathrm{mg} / \mathrm{dl}$ had an HDL level $>40 \mathrm{mg} / \mathrm{dl}$, and $80 \%$ of men (average of $1.33 \mathrm{mg} / \mathrm{dl}$ ) had levels $>50 \mathrm{mg} / \mathrm{dl}$. The worst results were recorded for LDL cholesterol. Nine percent of women and $12 \%$ of men had LDL levels $<100 \mathrm{mg} / \mathrm{dl}$. In a study by Kudaj-Kurowska et al., the concentration of the HDL fraction was above goal in $65 \%$ of men and $64 \%$ of women, and the concentration of the LDL fraction meeting the target goal was $38 \%$ in the entire study [22].

In our study, the level of physical activity influences the metabolic control of diabetes. The disease management was significantly higher in patients with sufficient and high physical activity levels (W=82\% and $\mathrm{M}=88 \%$ ) than in patients with insufficient levels of activity. Physical activity was crucial for postprandial glucose level and glycosylated hemoglobin control in both groups. The small percentage of patients with a high level of physical activity ( $\mathrm{W}=11 \%$ and $\mathrm{M}=12 \%$ ) and the high percentage of patients with insufficient (W=57\% and $\mathrm{M}=54 \%$ ) physical activity are disturbing. According to WHO recommendations, patients with diabetes should spend 150 minutes performing moderate activities or 75 minutes performing intense exercises a week [27]. However, according to our study, only approximately $20 \%$ of the examined population met these criteria, a result supported by randomized research studies.

Król et al. showed that $22 \%$ of the study group had a sedentary lifestyle and $27 \%$ perform less than 30 minutes of physical activity a day [28]. Markowicz et al. evaluated patients' physical activity with the IPAQ questionnaire and found that patients with high physical activity levels had significantly lower BMIs and higher weekly activity times. Eight-two percent of the population with moderate to high activity levels achieved good glycemic control [29]. Castaneda et al. noticed an improvement in metabolic parameters and a lower risk of cardiovascular derangements after 16 weeks of monitoring 62 Latino older adults with type 2 diabetes who were randomly assigned to a supervised progressive resistance training (PPT) or a control group [30].

The collected data shows a population where $83 \%$ of women and $78 \%$ of men do not smoke. Forty-eight percent of women and $16 \%$ of men in our study have never smoked. The best diabetic management was observed in people who were past smokers ( $\mathrm{W}=52 \%$ and $\mathrm{M}=82 \%$ ). Only a small percentage of active smokers were able to manage the condition ( $\mathrm{W}=17 \%$ and $\mathrm{M}=22 \%)$. There is a relationship between smoking and metabolic management of diabetes in the available literature. The majority (89\%) of the patients examined by Kary et al. were convinced of the harmfulness of smoking and the negative impact of tobacco on the body [31]. In research by Liwińska-Mossoń et al., higher insulin levels, total cholesterol levels, and VLDL levels with a simultaneous reduction of the HDL fraction were observed in the serum of smokers compared to non-smokers [32]. Yoshikawa et al., proved that smokers had worse glycemic control and glycosylated hemoglobin levels than non-smokers [33].

In the management of diabetes, a patient's positive attitude plays a huge role. A few meta-analyses evaluating the role of stress on diabetes management in the available literature. Despite these studies, there is a lack of research on the dependencies between managing a chronic disease and stress. Based on the available literature, we can say that the emotional support of patients is crucial. Minimizing chronic stress, creating a sense of security, and motivating patients to follow recommendations can result in a more effective therapeutic protocol. Kurowska's research has shown that patients with type 2 diabetes are given the most extensive educational support and negligible emotional support [34].

\section{Conclusions}

Smoking is standard for $25 \%$ of respondents. Over half of men often consume alcohol once a week. A significant majority of women do not drink or seldom drink alcohol.

Metabolic management of diabetes is insignificant. Dietary choices and physical activity levels are two factors that can have a significant influence on diabetes. The highest percentage of patients achieving disease management was observed in respondents with high physical activity levels. 


\section{Disclosures and acknowledgments}

The authors declare no potential conflicts of interest with respect to the research, authorship, and/or publication of this article. This work was funded by the authors.

\section{References:}

1. Czupryniak L, Strojek K. [Diabetology]. Gdańsk: Via Medica; 2016 (in Polish).

2. Chudiak A, Lomper K, Jankowska-Polańska B, Uchmanowicz I. [The impact of diabetes education on the assessment of the quality of life of patients type 2 diabetes]. Problemy Pielęgniarstwa. 2015; 23(1): 1-6 (in Polish). https://doi.org/10.5603/PP.2015.0001

3. International Diabetes Federation. IDF diabetes atlas. 7th edition. Brussels: International Diabetes Federation; 2015.

4. International Diabetes Federation. IDG diabetes atlas. 6th edition. Brussels: International Diabetes Federation; 2013.

5. Wróbel M. [Diabetes epidemiology]. In: Strojek K., editor. [Diabetology - practical guide]. Poznań: Termedia; 2014. p. 9-20 (in Polish).

6. naukowawpolsce.pap.pl [Internet]. Warszawa: Fundacja PAP; 2014. [Diabetes, hidden pandemic, situation in Poland, 2014 edition] [cited 2021 Aug 30]. Available from: http://naukowawpolsce.pap.pl/06.20.2015 (in Polish).

7. Badurek S. [Polish Diabetes Association recommendations 2017. The most important changes and rules for the general practitioners]. Lek w Polsce. 2017; 27(312): 51-55 (in Polish).

8. Chrostowska M, Strojek K, Zdrojewski K, Narkiewicz K. [Hypertension and diabetes]. In: Sieradzki J., editor. [Diabetes, vol. 2]. Gdańsk: Via Medica; 2016. p. 683-702 (in Polish).

9. Duczak A, Jankowska-Polańska B. [Lifestyle of the patients with type 2 diabetes]. Współczesne Pielęgniarstwo i Ochrona Zdrowia. 2013; 2(3): 50-54 (in Polish).

10. Janeczko D. [Epidemiology of type 2 diabetes]. In: Sieradzki J., editor. [Diabetes, vol. 1]. Gdańsk: Via Medica; 2015. p. 124-142 (in Polish).

11. The Emerging Risk Factors Collaboration. Diabetes mellitus, fasting blood glucose concentration, and risk of vascular disease: a collaborative meta-analysis of 102 prospective studies. Emerging Risk Factors Collaboration. Lancet. 2010; 26(375): 2215-2222. https://doi.org/10.1016/S0140-6736(10)60484-9

12. Bourne RR, Stevens GA, White RA, Smith JL, Flaxman SR, Price H, et al. Causes of vision loss worldwide, 1990-2010: a systematic analysis. Lancet Global Health 2013; 1: e339-e349. https://doi.org/10.1016/S2214109X(13)70113-X

13. Polish Diabetes Association. [Clinical recommendations for the management of diabetic patients]. Diabetologia Praktyczna. 2018; 4(1) (in Polish).

14. Human Nutrition Committee. KomPAN questionnaire [Internet]. Warsaw: Human Nutrition Committee [cited 2021 Aug 30]. Available from: https://www.knozc.pan.pl/index.php?option=com_content\&view=article\& id=136:kwestionariusz-do-badania-pogladow-i-zwyczajow-zywieniowych-oraz-procedura-opracowaniadanych-kompan-wersja-polskojezyczna-wydanie-drugie\&catid=36\&Itemid=129\&lang=pl (in Polish).

15. Juczyński Z, Ogińska-Bulik N. [Stress assessment tools and tools for coping with stress]. Warszawa: Pracownia Testów Psychologicznych; 2009 (in Polish).

16. Biernat E, Stupnicki R, Gajewski AK. [International Physical Activity Questionnaire (IPAQ) - Polish version]. Wychowanie Fizyczne i Sport. 2007; 51(1): 47-54 (in Polish).

17. Zandecki Ł, Janion-Sadowska A, Kurzawski J, Janion M. Diabetes, pre-diabetes and cardiovascular diseases in light of the 2019 ESC Guidelines. Medical Studies/Studia Medyczne. 2020; 36(2): 148-155. https://doi.org/10.5114/ms.2020.96796

18. Fabian W, Majkowska L, Molęda P, Stefański A. [The metabolic control in type 2 diabetic patients according to Polish Diabetes Association recommendation]. Polskie Archiwum Medycyny Wewnętrznej. 2006; CXVI(2): 760-765 (in Polish).

19. Szymborska-Kajanek A, Koblik T, Bandurska-Stankiewicz E. [Metabolic control in type 2 diabetic patients treated by general practitioners and referred to the specialists - preliminary results of the project "The Improvement of Glycaemic Control"]. Diabetologia Praktyczna. 2009; 10: 228-233 (in Polish).

20. Witek PW, Wołkow P, Stancel-Możwiłło J. The Polish Diabetes Registry for Adults a pilot study. Diabetologia Kliniczna. 2012; 1: 3-11. 
21. Jankowski M, Bała MM, Płaczkiewicz-Jankowska E, Topór-Mądry R, Mejza F, Jaeschke R, et al. Specialty outpatient care of diabetic patients in Poland - are we far from treatment targets? Rationale, design, and preliminary results of the OPTIMO study. Pol. Arch. Med. Wewn. 2011; 121: 375-383.

22. Kudaj-Kurowska A, Turek I, Józefowska M, Przech E, Cypryk K. [The metabolic control in type 2 diabetic patients according to Polish Diabetes Association recommendation]. Diabetologia Kliniczna. 2014; 3: 92-99 (in Polish).

23. Gudbjörnsdottir S, Cederholm J, Nilsson P.M. Eliasson B, the Steering Committee of the Swedish National Diabetes Register. The National Diabetes Register in Sweden: an implementation of the St. Vincent Declaration for Quality Improvement in Diabetes Care. Diabetes Care. 2003; 26: 1270-1276. https://doi.org/10.2337/ diacare.26.4.1270

24. Charpentier G, Genès N, Vaur L, Amar J, Clerson P, Camboue JP, et al. Control of diabetes and cardiovascular risk factors in patients with type 2 diabetes: a nationwide French survey. Diabetes Metab. 2003; 29(2): 152158. https://doi.org/10.1016/S1262-3636(07)70022-8

25. Orozco-Beltrán D, Gil-Guillen VF, Quirce F, Navarro-Perez J, Pineda M, Gomez-de-la-Cámara A, et al. Control of diabetes and cardiovascular risk factors in patients with type 2 diabetes in primary care. The gap between guidelines and reality in Spain. Int. J. Clin. Pract. 2007; 61(6): 909-915. https://doi.org/10.1111/j.17421241.2007.01367.x

26. Hoerger TJ, Segel JE, Gregg EW, Saaddine JB. Is glycemic control improving in U.S. adults?. Diabetes Care. 2008; 31: 81-86.

27. Colberg SR, Sigal RJ, Yardley JE, Riddell MC, Dunstan DW, Dempsey PC, et al. Physical activity/exercise and diabetes: a position statement of the American Diabetes Association. Diabetes Care. 2016; 39(11): 20652079. https://doi.org/10.2337/dc16-1728

28. Król H, Zboina B, Nowak- Starz G, Szpringer M, Zięba E, Biskup M. [Lifestyle of persons with type 2 diabetes]. Zdrowie Dobrostan. 2013; 4: 149-156 (in Polish).

29. Markowicz A, Molsa M, Tłuczykont M, Grzeszczak W, Strojek K. [Knowledge about physical activity in type 2 diabetic patients, practical performance, influence on body mass and glycaemic control]. Problemy Medycyny Rodzinnej. 2011; XIII(1): 5-8 (in Polish).

30. Castaneda C, Foldvari M, Gordon PL, Layne JE, Munoz Orians L, Nelson ME, et al. A randomized controlled trial of resistance exercise training to improve glycemic control in older adults with type 2 diabetes. Diabetes Care. 2002; 25: 233-234. https://doi.org/10.2337/diacare.25.12.2335

31. Kara I, Zysnarska M, Adamek R, Kalupa W, Gromadecka-Sutkiewicz M, Nowicka T, et al. [Tobacco smoking, alcohol consumption and physical activity among patients with type 2 diabetes]. Przegląd Lekarski. 2012; 69(10), 944-946 (in Polish).

32. Liwińska-Mossoń M, Milnerowicz H. [Smoking and the development, progression and treatment of diabetes]. Przegląd Lekarski. 2011; 68(10): 1005-1008 (in Polish).

33. Yoshikawa H, Hellstrom-Lindahl E, Grill V. Evidence for functional nicotinic receptors on pancreatic beta cells. Metabolism. 2005; 54: 247. https://doi.org/10.1016/j.metabol.2004.08.020

34. Kurowska K, Frąckowiak M. [Social support and coping with chronic disease as exemplified by type 2 diabetes]. Diabetologia Praktyczna. 2010; 11(3): 101-107 (in Polish). 